\title{
THE EFFECTS OF TEACHING MODEL AND VOCABULARY MASTERY TOWARDS STUDENTS WRITING ACHIEVEMENT
}

\author{
Atri Apriyani ${ }^{1}$, \\ Muhammad Sulhan ${ }^{2}$ \\ Postgraduate Program, English Language and Education \\ Universitas Indpraprasta PGRI \\ e-mail: a3anda14@gmail.com ${ }^{1}$ \\ e-mail: muhammad.sulhan@ unindra.ac.id $^{2}$
}

\begin{abstract}
This study was to know the teaching model and vocabulary mastery by students at state vocational high schools in Tangerang Regency when writing. The research methodology that is used is the experimental method. The population in this research was all of the $10^{\text {th }}$-grade students, with 680 students. The research findings are: 1) There is a significant effect of teaching model towards students writing achievement at State Vocational High School in Tangerang Regency. That is proved by sig value $=0.000<0.05$ and Faccount $=29.298$. 2) There is a significant effect of vocabulary mastery towards students writing achievement at State Vocational High School Tangerang Regency. That is proved by sig value $=0.000<0.05$ and Faccount $=17.945$. 3) There are no significant interactive effects of teaching model and vocabulary mastery towards students writing achievement at State Vocational High School Tangerang Regency. That is proved by sig value $=0.041<0.05$ and Faccount $=4.486$.
\end{abstract}

Keywords: Teaching model; vocabulary mastery; writing achievement.

\section{Introduction}

Students as the object of English learning activity at school are demanded to love this language first. The teacher should be more active and creative to create a successful teaching and learning activity to make that condition. The children are more likely to be interested in it if it is in a fun situation. Especially for vocabulary, the teacher should teach it to the students in the right way because it is the essential component of English. Many teachers worry about their students who do not retain the vocabulary they learn during a school year. Technology is changing the way we teach and learn languages; it has provided teachers with new facilities and approaches to teaching that can stimulate learners' interest while challenging their intellect (Blake, 2013, 2016; Stanley, 2013). Likewise, it has provided learners with plenty of creative and authentic resources that can facilitate the process of acquiring a new language (Walker \& White, 2013).

Similarly, Larsen-Freeman and Anderson (2011) state that technology contributes to language learning in two important ways: podcasts, online dictionaries, weblogs, and Web Boards. The tools enhance learning experiences, which increases access to the target language and opportunities for learners to work at their levels and pace and choose when and where to learn. They add that technology can engage learners in grammar, an essential process in second language acquisition. Larsen-Freeman (2003) said that grammar is "the ability to use grammar structures accurately, meaningfully" (p. 143). Technology gives learners the chance to see grammar as a skill, not merely as a set of abstract rules, and use that skill to choose the appropriate language form for contexts and meanings.

In addition to the variety of commercial games aimed primarily at the entertainment market, many digital games have been developed for educational purposes. Digital games, as with games in many other forms, provide a setting, rules, and constraints within which players can interact, either with each other or an aspect of the game environment, to achieve some form of goal. These can present problems to be solved, 


\section{INFERENCE: Journal of English Language Teaching}

Vol. 4, No. 3, December 2021 - March 2022

p-ISSN: 2615-8671

e-ISSN: 2615-868X

allow exploration of a model of some aspect of our world, invite collaboration, role play. Drawing on these qualities, the scope for facilitating learning and the educational value of digital games has for some time been of interest to many reviewers (Allsop, 2012; Robertson \& Howells, 2008; Spires, Rowe, Mott \& Lester, 2011 Buckingham, 2007). However, the implementation of digital games into primary classrooms is still at the beginning phase. While it appears that many children spend hours playing digital games and researchers continue to investigate the potential for learning with this medium, teachers are still not fully clear about their role in the game-based learning (GBL) environment (Future lab, 2006). Reasons for this may include a lack of established and transparent policy for both learnings through games and game making in schools about the teacher's role or not providing enough time for teachers to become familiar with the mechanics of digital games. However, another important reason could be teachers not having the pedagogical knowledge to teach digital games. According to Jessel (2012: 28), "Innovation arising from new technologies makes a variety of demands upon the role of the teacher." He continues, "At another level, the introduction of innovation makes significant demands upon teachers' pedagogical, professional and managerial skills (ibid: 28). Using traditional teaching methods may not be the most effective approach if teachers aim to maximize the potential of learning with digital games.

As new technologies evolve, it can be argued that the focus point should be moved from the technology itself towards developing a model so that teachers can consider how it can be used in terms of what can be achieved in practice and which pedagogical strategies need to be adopted. If games can provide a dynamic learning space that is extended in time, effective utilization may require different teaching strategies and classroom management skills. The writer aims to offer convenience to learn English using multimedia learning applications using Duolingo, which can be used to practice independently and in place of study/course/school/home or everywhere. To ease the process of learning the English language, and currently supported by very advanced technology, the young learners who want to learn English with practical and fun applications might use Duolingo to practice English. We can download the application on the phone or computer so that you can practice any time. Especially for the newbie, young English learners can practice anytime and anywhere. Duolingo has an excellent learning strategy because it has a very motivating learning system. It uses a strategy of game mechanics to create the incentive to keep students learning. It is built very similarly to a computer game where the participants have to pass certain levels.

A student passes the three levels of the language. The following lessons are unlocked after a learner has mastered the previous material. Users can complete a variety of exercise types, including multiple choices, writing, and speaking through a microphone. Duolingo uses mainly drills and repetitive exercises in the lessons (Veronika Jaskova Bc., "Duolingo as a New Language-Learning Website and Its Contribution to E-Learning Education" Diploma Thesis (Brno: Masaryk University, 2014) p.25). Duolingo deliberately brought the concept of "play and learned" to feel more comfortable and easier to use by all walks of life. We certainly have felt tired doing daily routines, and for a moment, we can relax while learning a foreign language. In learning a foreign language, vocabulary plays an important role. It is one element that links the four language skills of speaking, listening, reading, and writing. In order to communicate well in a foreign language, students should acquire an adequate number of words and know how to use them accurately. The acquisition of vocabulary would help people gain, understand, and enhance the process of knowledge transfer for a better life. Vocabulary is one of the English sub-skills that must be taught to the students because vocabulary has an essential role in all language skills. Wilkins (as cited in Thornbury, 2002:13) states that very little can be conveyed; nothing can be conveyed without vocabulary. In other words, the first thing that has to be mastered by language learners in learning language is vocabulary. In listening, students' vocabulary influences their understanding of the teacher a speech, class discussion, and other speeches. The words that they choose in speaking affect how well they deliver a message. In reading, students' vocabulary affects their ability to understand and comprehend a text. In addition to writing, students' vocabulary also influences how clear they convey their thoughts to the reader. In conclusion, vocabulary plays an important role in equipping students to be able to communicate in English.

Writing is a process to produce language. We can take more time to think and choose words to express our ideas, thoughts, and feelings, and then we revise if it is not clear to express what we intend to write. If we look at the teaching-learning process at schools, writing is challenging to learn, but it is essential for them to, especially in mastering short functional text-one kind of short functional text that students have to master. It also needs attention because it needs its principles and method; it requires 
mastery of grammatical a rhetorical device and conceptual and judgment. Because of that, it needs the practice to improve that skill. Writing is one crucial skill that should be known and mastered by the students."

Based on the phenomena above, the researcher tries to find an effective solution to improve students' vocabulary by using Duolingo Game in the teaching-learning process. Duolingo Game is a game for the whole class that encourages students to study and review their vocabulary words. There are some reasons why I choose Duolingo Game as the media to improve their vocabulary mastery. First, Duolingo Game can be used as one of the exciting activities to review their vocabulary during the lesson. It can attract the student's attention and their involvement in the teaching and learning process. Second, students can learn how to work and cooperate as a group and also learn how to appreciate each other. Third, Duolingo games can create an enjoyable environment. Students can enjoy fun and joyful learning. Fourth, Duolingo Game can help students revise their vocabulary and recall something that happened in the game. It may help students remember the language connected with it. Based on the background above, the writer wants to research with the title "The Effects of Teaching Model and Vocabulary Mastery towards Writing Achievement an Experiment at 10th Grade of State Vocational High School Tangerang Regency." Based on the background and identification of the problem above, the statement of the problem of this research are:

1. Is there any effect of the teaching model towards students writing achievement at state vocational high schools in Tangerang Regency?

2. Is vocabulary mastery on students writing achievement at state vocational high schools in Tangerang Regency?

3. Are there any interactive effects of teaching model and vocabulary mastery towards students writing achievement at state vocational high schools in Tangerang Regency?

\section{Method}

The research was performed on 10th students of two Public Vocational High Schools in Tangerang. The name of the schools is SMKN 3 and SMKN 11 in Tangerang Regency. All of them are included in Dinas Pendidikan Banten Province. The time of the research was spent about five months from September 2019 until January 2020.

Table 1

Factorial 2 X 2 Research Experiment Design

\begin{tabular}{|c|c|c|}
\hline \multirow{2}{*}{ Teaching Model (A) } & \multicolumn{2}{|c|}{ Teaching Model } \\
\cline { 2 - 3 } Vocabulary Mastery (B) & $\begin{array}{c}\text { Duolingo Game } \\
\left(\mathrm{A}_{1}\right)\end{array}$ & $\begin{array}{c}\text { Conventional } \\
\text { Teaching }\left(\mathrm{A}_{2}\right)\end{array}$ \\
\hline High Vocabulary Mastery $\left(\mathrm{B}_{1}\right)$ & $\mathrm{A}_{1} \mathrm{~B}_{1}$ & $\mathrm{~A}_{1} \mathrm{~B}_{2}$ \\
\hline Low Vocabulary Mastery $\left(\mathrm{B}_{2}\right)$ & $\mathrm{A}_{2} \mathrm{~B}_{1}$ & $\mathrm{~A}_{2} \mathrm{~B}_{2}$ \\
\hline
\end{tabular}

Best and Kahn (2006:13) said that: "Population is any group of individuals with one or more characteristic in common and that are of interest to the research." It describes that population is essential for conducting ay research and finalizing an essential conclusion about what the writer wants to prove the research's theory. A population is a large number of groups where the smalls took. Arikunto (2010: 130) said that: "population is a group of individuals or objects obtain in research. Population is all of the research subjects". According to Sugiono (2008:117), the population is an area of generalization that comprises objects or subjects with the quality and specific characteristics determined to be analyzed and then concluded by the researcher. The population can be target population and affordable population. The target population means the population which can be used as the result of the research in the generalization region. Meanwhile, affordable population means population, which can be used as the sample frame. In the research, the population was 10th-grade students of state vocational high school in Tangerang Regency, 


\section{INFERENCE: Journal of English Language Teaching}

Vol. 4, No. 3, December 2021 - March 2022

p-ISSN: 2615-8671

e-ISSN: 2615-868X

SMKN 3 Tangerang regency, and SMKN 11 Tangerang regency, in 2019/2020. The students' population showed 684 students, which the writer got from the administration department.

Table 2

The Population of the Research

\begin{tabular}{|c|l|l|}
\hline No & The Name of Schools & The Number of the Students \\
\hline 1 & SMKN 3 Kab. Tangerang & $\begin{array}{l}35 \text { Students } x 4 \text { classes }=140 \\
36 \text { students } x 4 \text { classes }=144\end{array}$ \\
\hline 2 & SMKN 11 Kab. Tangerang & 36 Students x 11 classes = 396 \\
\hline \multicolumn{2}{|c|}{ Total Population } & 680 Students \\
\hline
\end{tabular}

Table 3

The Specifications of the Vocabulary Instrument

\begin{tabular}{|l|l|l|l|c|}
\hline No & Item tests & Indicators & Number of Questions & Total items \\
\hline 1. & Completion & $\begin{array}{l}\text { Student is able to complete the sentence } \\
\text { with the appropriate word. }\end{array}$ & $\begin{array}{l}1,2,3,4,5,6,7,8,9,10,11, \\
12,13,14,15,16,17,18,19, \\
20\end{array}$ & 20 \\
\hline 2. & Synonym & $\begin{array}{l}\text { Student is able to know the word that has } \\
\text { the similar meaning. }\end{array}$ & $\begin{array}{l}21,22,23,24,25,26,27,28, \\
29,30\end{array}$ & 10 \\
\hline 3. & Antonym & $\begin{array}{l}\text { Student is able to know the word that is } \\
\text { opposite in meaning }\end{array}$ & $31,32,33,34,35,36,37,38$ & 8 \\
\hline 4. & Translation & $\begin{array}{l}\text { Students can match English with their } \\
\text { Indonesian equivalents. }\end{array}$ & $39,40,41,42,43,44$, & 6 \\
\hline 5. & Definition & $\begin{array}{l}\text { Student is a able to identify the given } \\
\text { word or determine the term of the given } \\
\text { description }\end{array}$ & $45,46,47,48,49,50$ & 6 \\
\hline
\end{tabular}

Table 4

The Difficulties of Vocabulary Mastery Instrument

\begin{tabular}{|c|c|c|c|c|c|}
\hline $\begin{array}{l}\text { No. } \\
\text { Item } \\
\end{array}$ & $\begin{array}{l}\text { Index } \\
\text { Difficulties }\end{array}$ & Result & No. Item & $\begin{array}{l}\text { Index } \\
\text { Difficulties }\end{array}$ & Result \\
\hline 1 & 0,733 & easy & 26 & 0,567 & midle \\
\hline 2 & 0,567 & midle & 27 & 0,467 & midle \\
\hline 3 & 0,867 & easy & 28 & 0,833 & easy \\
\hline 4 & 0,433 & midle & 29 & 0,533 & midle \\
\hline 5 & 0,733 & easy & 30 & 0,733 & easy \\
\hline 6 & 0,667 & midle & 31 & 0,600 & midle \\
\hline 7 & 0,767 & easy & 32 & 0,700 & easy \\
\hline 8 & 0,333 & midle & 33 & 0,767 & easy \\
\hline 9 & 0,533 & midle & 34 & 0,733 & easy \\
\hline 10 & 0,833 & easy & 35 & 0,667 & midle \\
\hline 11 & 0,400 & midle & 36 & 0,800 & easy \\
\hline 12 & 0,767 & easy & 37 & 0,533 & midle \\
\hline 13 & 0,667 & midle & 38 & 0,500 & midle \\
\hline 14 & 0,700 & easy & 39 & 0,500 & midle \\
\hline 15 & 0,567 & midle & 40 & 0,667 & midle \\
\hline 16 & 0,567 & midle & 41 & 0,767 & easy \\
\hline 17 & 0,467 & midle & 42 & 0,767 & easy \\
\hline
\end{tabular}


INFERENCE: Journal of English Language Teaching

Vol. 4, No. 3, December 2021 - March 2022

p-ISSN: 2615-8671

e-ISSN: $2615-868 X$

\begin{tabular}{|c|c|c|}
\hline $\begin{array}{l}\text { No. } \\
\text { Item }\end{array}$ & $\begin{array}{l}\text { Index } \\
\text { Difficulties }\end{array}$ & Result \\
\hline 18 & 0,800 & easy \\
\hline 19 & 0,667 & midle \\
\hline 20 & 0,767 & easy \\
\hline 21 & 0,733 & easy \\
\hline 22 & 0,733 & easy \\
\hline 23 & 0,667 & midle \\
\hline 24 & 0,433 & midle \\
\hline 25 & 0,433 & midle \\
\hline
\end{tabular}

\begin{tabular}{|l|l|l|}
\hline No. Item & $\begin{array}{l}\text { Index } \\
\text { Difficulties }\end{array}$ & Result \\
\hline 43 & 0,633 & midle \\
\hline 44 & 0,367 & midle \\
\hline 45 & 0,633 & midle \\
\hline 46 & 0,367 & midle \\
\hline 47 & 0,733 & easy \\
\hline 48 & 0,500 & midle \\
\hline 49 & 0,700 & easy \\
\hline 50 & 0,700 & easy \\
\hline
\end{tabular}

Table 5

The Validity of Vocabulary Mastery Instrument

\begin{tabular}{|c|c|c|c|c|c|}
\hline $\begin{array}{l}\text { No. } \\
\text { Item }\end{array}$ & $r$-bis & Result & No. Item & r-bis & Result \\
\hline 1 & 0,435 & valid & 26 & 0,402 & valid \\
\hline 2 & 0,445 & valid & 27 & 0,391 & valid \\
\hline 3 & 0,404 & valid & 28 & 0,470 & valid \\
\hline 4 & 0,384 & valid & 29 & 0,418 & valid \\
\hline 5 & 0,532 & valid & 30 & 0,637 & valid \\
\hline 6 & 0,417 & valid & 31 & 0,366 & drop \\
\hline 7 & 0,449 & valid & 32 & 0,533 & valid \\
\hline 8 & 0,409 & valid & 33 & 0,069 & drop \\
\hline 9 & 0,447 & valid & 34 & 0,507 & valid \\
\hline 10 & 0,527 & valid & 35 & 0,068 & drop \\
\hline 11 & 0,101 & drop & 36 & 0,461 & valid \\
\hline 12 & 0,576 & valid & 37 & 0,375 & valid \\
\hline 13 & 0,394 & valid & 38 & 0,522 & valid \\
\hline 14 & 0,432 & valid & 39 & 0,114 & drop \\
\hline 15 & 0,604 & valid & 40 & 0,379 & valid \\
\hline 16 & 0,474 & valid & 41 & 0,559 & valid \\
\hline 17 & 0,398 & valid & 42 & 0,559 & valid \\
\hline 18 & 0,139 & drop & 43 & 0,390 & valid \\
\hline 19 & 0,796 & valid & 44 & 0,240 & drop \\
\hline 20 & 0,728 & valid & 45 & 0,605 & valid \\
\hline 21 & 0,669 & valid & 46 & 0,411 & valid \\
\hline 22 & 0,628 & valid & 47 & 0,459 & valid \\
\hline 23 & 0,394 & valid & 48 & 0,200 & drop \\
\hline 24 & 0,384 & valid & 49 & 0,432 & valid \\
\hline 25 & 0,492 & valid & 50 & 0,385 & valid \\
\hline
\end{tabular}


Table 6

Specification of the Writing Achievement

\begin{tabular}{|l|l|c|}
\hline No & \multicolumn{1}{|c|}{ Indicators } & Score \\
\hline 1. & Students are able to write the content of daily routine & $\mathbf{3 0}$ \\
\hline 2. & Students are able to retell a series of events & $\mathbf{2 5}$ \\
\hline 3. & Students can write the tense well & $\mathbf{2 5}$ \\
\hline 4. & Student can show vocabulary & $\mathbf{2 0}$ \\
\hline \multicolumn{2}{|l|}{ Total Score } & $\mathbf{1 0 0}$ \\
\hline
\end{tabular}

Table 7

The Validity of Writing Achievement Instrument

\begin{tabular}{|c|c|c|}
\hline $\begin{array}{c}\text { No. } \\
\text { Item }\end{array}$ & r-pearson & Result \\
\hline 1 & 0,702 & valid \\
\hline 2 & 0,770 & valid \\
\hline 3 & 0,845 & valid \\
\hline 4 & 0,762 & valid \\
\hline
\end{tabular}

Table 9

Prices Required for a Bartlett Test

\begin{tabular}{|c|c|c|c|c|c|}
\hline Sample Group & Dk & $1 / \mathrm{dk}$ & $\mathrm{S}_{1}{ }^{2}$ & $\log \mathrm{s}_{\mathrm{i}}^{2}$ & $(\mathrm{dk}) \log \mathrm{s}_{\mathrm{i}}^{2}$ \\
\hline 1 & 2 & 3 & 4 & 5 & 6 \\
\hline KT & $\mathrm{n}_{1}-1$ & $1 /\left(\mathrm{n}_{1}-1\right)$ & $\mathrm{S}_{\mathrm{kt}}^{2}$ & $\log \mathrm{Skt}^{2}$ & $\left(\mathrm{n}_{1}-1\right) \log \mathrm{S}_{\mathrm{KT}}{ }^{2}$ \\
\hline KR & $\mathrm{n}_{2}-1$ & $1 /\left(\mathrm{n}_{2}-1\right)$ & $\mathrm{S}_{\mathrm{kr}}^{2}$ & $\log \mathrm{S}_{\mathrm{kr}}^{2}$ & $\left(\mathrm{n}_{2}-1\right) \log \mathrm{S}_{\mathrm{KR}}^{2}$ \\
\hline RT & $\mathrm{n}_{3}-1$ & $1 /\left(\mathrm{n}_{3}-1\right)$ & $\overline{\mathrm{S}_{\mathrm{rt}}^{2}}$ & $\log \mathrm{S}_{\mathrm{rt}}^{2}$ & $\left(\mathrm{n}_{3}-1\right) \log \mathrm{S}_{\mathrm{RT}}{ }^{2}$ \\
\hline RR & $\mathrm{n}_{4}-1$ & $1 /\left(\mathrm{n}_{4}-1\right)$ & $\overline{\mathrm{S}_{\mathrm{rr}}^{2}}$ & $\log \mathrm{S}_{\mathrm{rr}}^{2}$ & $\left(\mathrm{n}_{4}-1\right) \log \mathrm{S}_{\mathrm{RR}}^{2}$ \\
\hline $\bar{\Sigma}$ & $\sum\left(\mathrm{n}_{\mathrm{i}}-1\right)$ & $\sum 1 /\left(\mathrm{n}_{\mathrm{i}}-1\right)$ & - & - & $\sum\left(n_{1}-1\right) \log S_{i}^{2}$ \\
\hline
\end{tabular}

\section{Results and Discussions}

\section{Student Learning Outcomes Group's Student's Writing Achievement Which Uses Duolingo Game Teaching Model (A1)}

Students' writing achievement with the Duolingo Game teaching model (A1) has a theoretical score range of $0-100$. The research results are obtained by minimum score is 66 , and the maximum score is 85 , mean score $(\mathrm{X})$ is 72.25 , and the standard deviation is 6.584 . The descriptions frequency shows that of 20 students as the sample in the group of students who were given Duolingo Game contained $20 \%$ of students obtain the learning outcomes student's writing achievement above average, $30 \%$ of students are on average, and $50 \%$ of students below average. 
Tabel 10

Data Descript Writing Achievement

Descriptive Statistics

\begin{tabular}{|c|c|c|c|c|c|}
\hline & N & Minimum & Maximum & Mean & Std. Deviation \\
\hline A1 & 20 & 60,00 & 85,00 & 72,2500 & 6,58447 \\
A2 & 20 & 40,00 & 80,00 & 60,7500 & 9,77039 \\
B1 & 20 & 60,00 & 85,00 & 71,0000 & 6,99624 \\
B2 & 20 & 40,00 & 80,00 & 62,0000 & 10,80935 \\
A1B1 & 10 & 65,00 & 85,00 & 74,5000 & 5,98609 \\
A1B2 & 10 & 60,00 & 80,00 & 70,0000 & 6,66667 \\
A2B1 & 10 & 60,00 & 80,00 & 67,5000 & 6,34648 \\
A2B2 & 10 & 40,00 & 65,00 & 54,0000 & 7,74597 \\
Valid N (listwise) & 10 & & & & \\
& & & & & \\
\hline
\end{tabular}

\section{Student Learning Outcomes Group's Student's Writing achievement which uses Conventional Teaching (A2)}

Description of student's writing achievement model given a Conventional Teaching (A2) has a theoretical score range $0-100$. The research results are obtained by minimum score is 40 and score maximum score is 80 , mean score (mean) is 60.75 , and the standard deviation is 9.770 . The table shows that of 20 students as the sample in the group of students who were given Conventional Teaching, there are 50\% of students obtain the learning outcomes student's writing achievement above the average, $15 \%$ of students are on average $35 \%$ of students are below average

\section{Student Learning Outcomes Group's Student's Writing Achievement with High Vocabulary Mastery (B1)}

Description of student's writing achievement model with high vocabulary mastery overall (B1) has a theoretical range of $0-100$. The research results are obtained by a minimum score of 60 , and the maximum score is 85 , the mean score (mean) is 71.00 , and the standard deviation is 6.996 . The table shows that of 20 students as the sample in learning outcomes student's writing achievement in the group of students who have a high Vocabulary mastery, there are $60 \%$ students have Student's Writing achievement above average, 25\% of students that is on average, and $15 \%$ of students are below average.

Student Learning Outcomes Group's Student's Writing achievement with Low Vocabulary Mastery (B2)

Student learning outcomes group's writing achievement with low vocabulary mastery overall (B2) has a theoretical range of $0-100$. The research results are obtained by minimum score is 40 , and the maximum score is 80 , mean score (mean) is 62.00 , and the standard deviation is 10.809 .

Student learning outcomes group's Student's Writing achievement which uses Duolingo Game Teaching model and whose high Vocabulary Mastery (A1B1)

The description of student learning outcomes group's student's writing achievement uses Duolingo game teaching model and whose high vocabulary mastery (A1B1) to obtain the theoretical score range 0100. The research results are obtained by a minimum score of 65 , and the maximum score is 85 , the mean score is 74.50, and the standard deviation of 5.986. The table shows that of 10 students as the sample group learning outcomes student's writing achievement is given Duolingo Game on students who have a high vocabulary mastery, there are $30 \%$ of students obtain the learning outcomes student's writing achievement above on average, $30 \%$ of students are on average, and $40 \%$ of students are below average.

Student learning outcomes group's Student's Writing Achievement uses Duolingo Game Teaching Model and Low Vocabulary Mastery (A1B2).

Description of student learning outcomes' student's writing achievement by providing learning model Duolingo Game teaching model on students with low vocabulary mastery (A1B2) has a theoretical score range $0-100$. The minimum score obtains the research results is 60 , the maximum score is 80 , the mean score of 70.00 , and the standard deviation of 6.667 . 
The table and histogram above show that of 10 students as the sample in the group lessons are given Duolingo Game Teaching model on students who have low vocabulary mastery, there are $40 \%$ students acquire learning outcomes student's writing achievement above average, 30\% of students are on average, and $30 \%$ of students are below average.

Student learning outcomes group's Student's Writing achievement which uses Conventional Teaching and whose high Vocabulary Mastery (A2B1)

Description of student's writing achievement in providing Conventional Teaching to students with a high vocabulary mastery (A2B1) has a theoretical score of $0-100$. The research results are obtained by minimum score is 60 , and the maximum score is 80 , mean score is 67.5 , and the standard deviation is 6.346 . The table shows that of 10 students as the sample group learning outcomes student's writing achievement in providing Conventional Teaching to students who have a vocabulary mastery high, there are $20 \%$ student's writing achievement above on average, $20 \%$ of students are on average, and $60 \%$ of students are below average.

\section{Learning outcomes group's Student's Writing achievement which uses Conventional Teaching and whose Low Vocabulary Mastery (A2B2)}

Description of the results of students' writing achievement using Conventional Teaching on students with low vocabulary mastery (A2B2) has a theoretical score of $0-100$. The research results are obtained by a minimum score of 40 , and the maximum score is 65.00 , the mean score is 54.00 , and the standard deviation is 7.746. The table shows that of 10 students as the sample group learning outcomes student's writing achievement in giving Duolingo Game teaching model on students who have low vocabulary mastery, there are $30 \%$ student's writing achievement above average, $20 \%$ of students are on average, and $50 \%$ of students are below average.

Table 11

Data Normality Test Kolmogorov-Smirnov on Significance Level Of $\square=0.05$

\begin{tabular}{|c|c|c|c|c|c|c|c|c|c|}
\hline & & & & & & & & \\
\hline \multicolumn{2}{|l|}{$\mathrm{N}$} & 20 & 20 & 20 & 20 & 10 & 10 & 10 & 10 \\
\hline \multirow{2}{*}{$\begin{array}{l}\text { Normal } \\
\text { Parameter } \\
\mathrm{s}^{\mathrm{a}, \mathrm{b}}\end{array}$} & Mean & 72,25 & 60,75 & 71 & 62 & 74,5 & 70 & 67,5 & 54 \\
\hline & $\begin{array}{l}\text { Std. } \\
\text { Deviation }\end{array}$ & 6,58447 & 9,77039 & 6,99624 & 10,80935 & 5,98609 & 6,66667 & 6,34648 & 7,74597 \\
\hline \multirow{4}{*}{$\begin{array}{l}\text { Most } \\
\text { Extreme } \\
\text { Difference } \\
\text { s } \\
\text { Test Statisti }\end{array}$} & Absolute & 0,166 & 0,168 & 0,157 & 0,12 & 0,174 & 0,2 & 0,253 & 0,203 \\
\hline & Positive & 0,138 & 0,132 & 0,157 & 0,117 & 0,174 & 0,133 & 0,253 & 0,197 \\
\hline & Negative & $-0,166$ & $-0,168$ & $-0,116$ & $-0,12$ & $-0,133$ & $-0,2$ & $-0,147$ & $-0,203$ \\
\hline & & 0,166 & 0,168 & 0,157 & 0,12 & 0,174 & 0,2 & 0,253 & 0,203 \\
\hline \multicolumn{2}{|c|}{ Asymp. Sig. (2-tailed) } &, $149^{\circ}$ &, $140^{\circ}$ &, $200^{\mathrm{c}, \mathrm{d}}$ &, $200^{\mathrm{c}, \mathrm{d}}$ &, $200^{\mathrm{c}, \mathrm{d}}$ &, $200^{\mathrm{c}, \mathrm{d}}$ &, $069^{c}$ & $200^{\mathrm{c}, \mathrm{d}}$ \\
\hline
\end{tabular}

Table 11 above shows that all groups of data normality were tested with the Kolmogorov-Smirnov test with SPSS provides significant value Asymp. Sig. (2-tailed)) in column-Smirnov Kolmogorov amounted $\mathrm{A} 1=.149, \mathrm{~A} 2=.140, \mathrm{~B} 1=.200, \mathrm{~B} 2=.200, \mathrm{~A} 1 \mathrm{~B} 1=.200, \mathrm{~A} 1 \mathrm{~B} 2=.200, \mathrm{~A} 2 \mathrm{~B} 1=.069$, and $\mathrm{A} 2 \mathrm{~B} 2=.200$. Then all the sig has a value $>0.05$ level. Thus, it concluded that this study's eight groups of data come from a normally distributed population. This suggests that one of the prerequisites of the F-test in the study has been met. 
Table 12

Homogeneity Test

Levene's Test of Equality of Error Variances

Dependent Variable: Writing Achievement

\begin{tabular}{|c|l|l|l|}
\hline \multicolumn{1}{|c|}{$F$} & \multicolumn{1}{|c|}{$\mathrm{df1}$} & $\mathrm{df2}$ & Sig. \\
\hline, 232 & 3 & 36 &, 873
\end{tabular}

Tests the null hypothesis that the error variance of the dependent variable is equal across groups.

a. Design: Intercept + Model + Vocabulary + Model * Vocabulary

The requirement is that the data homogeneity significant value count $>$ significant values $(0.05)$. The null hypothesis (Ho) is accepted as per the requirements. The homogeneity test results of the three data groups obtained are mean values $(0.873>0: 05)$. It can be concluded that the data Student's Writing achievement of three sets of data has the same population variance or the data across treatment groups derived from a homogeneous population.

\section{The Research Hypothesis Test}

\section{Table 13}

Tests of Between-Subjects Effects

Dependent Variable: Writing Achievement

\begin{tabular}{|c|c|c|c|c|c|}
\hline Source & $\begin{array}{c}\text { Type III Sum of } \\
\text { Squares }\end{array}$ & df & Mean Square & F & Sig. \\
\hline Corrected Model & $2335,000^{\mathrm{a}}$ & 3 & 778,333 & 17,243 &, 000 \\
Intercept & 176890,000 & 1 & 176890,000 & 3918,794 &, 000 \\
Model & 1322,500 & 1 & 1322,500 & 29,298 &, 000 \\
Vocabulary & 810,000 & 1 & 810,000 & 17,945 &, 000 \\
Model * Vocabulary & 202,500 & 1 & 202,500 & 4,486 &, 041 \\
Error & 1625,000 & 36 & 45,139 & & \\
Total & 180850,000 & 40 & & & \\
Corrected Total & 3960,000 & 39 & & \\
\hline
\end{tabular}

Table 14

Continue with Test tables Tukey

Multiple Comparisons

Dependent Variable: Writing Achievement

Tukey HSD

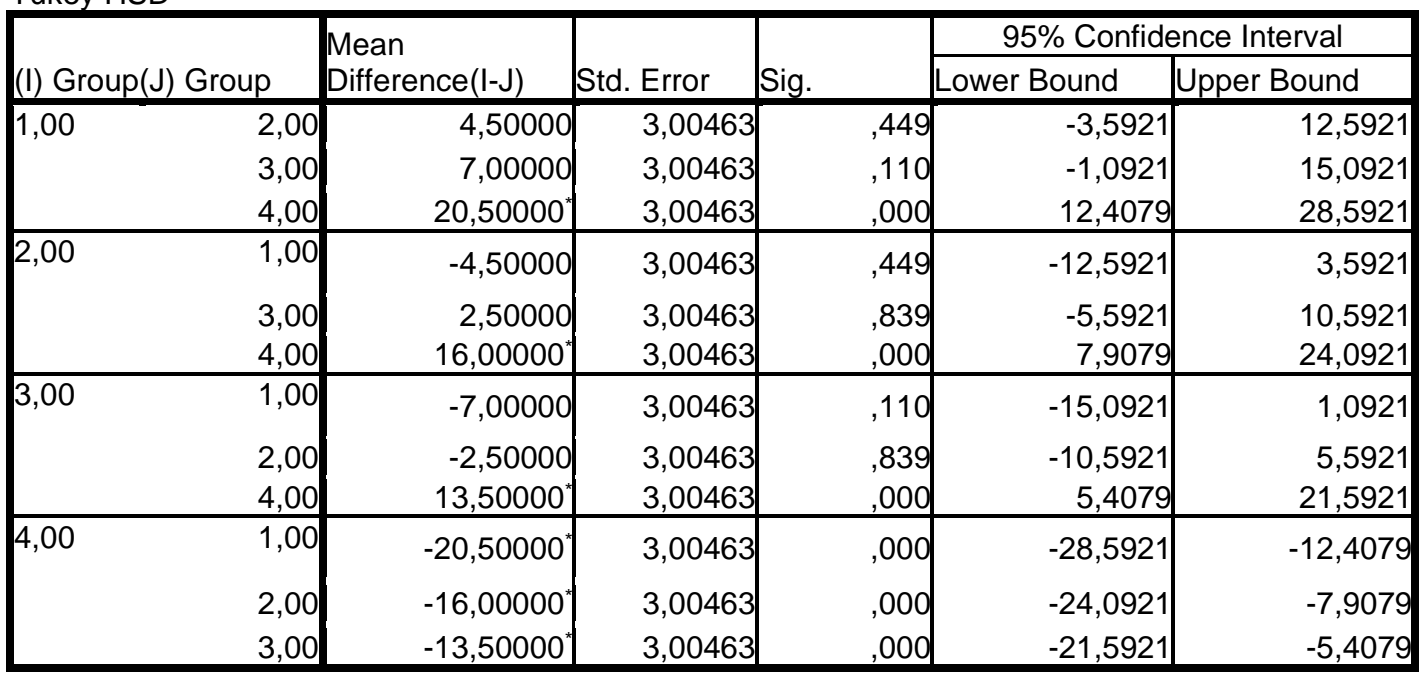

*. The mean difference is significant at the 0.05 level. 


\section{The Effect of Teaching Model towards student's Writing Achievement}

The Test of Between-Subject Effects table is the main table that presents the results of the proposed research hypotheses. From this table, it is known p-value for the category of Teaching model (hypothesis-1) is sig $0.000<0.05$ and Faccount $=29.298$, the conclusion to the first hypothesis is that there is a significant difference granting Teaching model for Student's Writing achievement in giving Duolingo Game and Conventional Teaching. The teaching model used by the teacher will affect the ability to write achievement. Students can actively learn if students are allowed to learn to solve their learning problems.

Duolingo has an excellent learning strategy because it has a very motivating learning system. It uses a strategy of game mechanics to create the incentive to keep students learning. It is built very similarly to a computer game where the participants have to pass certain levels. A student passes the three levels of the language. The following lessons are unlocked after a learner has mastered the previous material. Users can complete a variety of exercise types, including multiple choices, writing, and speaking through a microphone. Duolingo uses mainly drills and repetitive exercises in the lessons. Duolingo deliberately brought the concept of "play and learned" to feel more comfortable and easier to use by all walks of life. We certainly have felt tired doing daily routines, and for a moment, we can relax while learning a foreign language. Based on quantitative and qualitative information above, it is concluded that there is significant effects teaching model on students' writing achievement.

\section{The Effect of Vocabulary Mastery towards Student's Writing Achievement}

The Test of Between-Subject Effects table is the main table that presents the results of the proposed research hypotheses. From this table, it is known p-value for the category of vocabulary mastery (hypothesis-2) is sig $0.000<0.05$ and $\mathrm{F}$ account $=17.945$, the conclusion to the first hypothesis is that there is a significant difference in granting vocabulary mastery for student's writing achievement with high and low vocabulary mastery. To be successful in writing, vocabulary is the basic competence that students must reach to get other competencies like reading, writing, listening, and speaking. In order to communicate well, the students need to have the adequate vocabulary. It is challenging to master the other competencies without mastering and understanding the vocabulary well. In learning English, students should know about vocabulary because by knowing the words, they will try how to use it to express their ideas and communicate. The vocabulary cannot be separated from other aspects of language. So, it is announced that using the Duolingo game could be bringing an affirmative effect on students writing achievement. Based on quantitative and qualitative information above, it is concluded that there is a significant effect of vocabulary mastery on students' writing achievement.

\section{The Interactive Effects of Teaching Model and Vocabulary Mastery towards student's Writing achievement}

Furthermore, from table test of Between-Subject Effects are also known p-value for interaction and Teaching model-vocabulary mastery $\left(\mathrm{A}^{*} \mathrm{~B}\right)$ is $0.041<0.05$ and $\mathrm{F}$ account $=4.486$, the conclusion to the third hypothesis is that there is a significant difference in the interaction factor category with the teaching model and vocabulary mastery toward student's writing achievement. Based on the advanced test (Tukey test), results can be summed up:

a) The Mean Difference (IJ) with the A1B2 A1B1 group is 4.50, and the test results obtained sig = $0.449>0.05$, so it is concluded that there are no significant differences between the groups A1B1 with A1B2

b) The Mean Difference (IJ) with the A2B1 A1B1 group is 7.00, and the test results obtained sig = $0.110>0.05$ so that concluded there is no significant difference between groups A1B1 with A2B 1

c) The Mean Difference (IJ) with the A1B2 A2B2 group is 16.00, and the test results obtained sig = $0.000<0.05$, so that concluded there is a significant difference between groups A1B2 with $\mathrm{A} 2 \mathrm{~B} 2$

d) The Mean Difference (IJ). A2B1 group with A2B2 is 13.50, and the test results obtained sig = $0.000<0.05$, which concluded there are significant differences between the groups A2B1 with A2B2.

Duolingo is a very smart app. For example, in a translation exercise, learners type I'm not a teacher" instead of "I'm not a teacher," the app will know this is a typo and not a mistake. The learners pass the exercise but are reminded of the typographical error in their answers. Another attractive characteristic of the 
app is the Dumbbell button that learners can use from the home page of their course. Through this feature, Duolingo offers personalized exercises for each learner, focusing on their weaknesses and improving their skills. To Duolingo, learners can add friends and use this feature to communicate and/or compete with them. By finishing a lesson successfully, they gain (10) XPs and see the number of XPs their friends have scored.

Moreover, Duolingo users can make the app notify them when someone has more points than them (setting > someone passes me) which can be very motivating. It must be noted that Duolingo does not provide any grammatical explanations. It only immerses the learner in the target language by offering exercises centered on new vocabulary. To learn grammar, learners must deduce the principles of grammar on their own and through trial and error. Even though Duolingo penalizes the learners for the tiniest of mistakes and points out the most insignificant typos, it does not present the learners with any grammar notes or rules of any kind. Should learners make a mistake in the new language, Duolingo shows them where they have made a mistake, but they will have to work out the rule independently. Based on the quantitative and qualitative information above. It can be concluded that there is a significant interactive effect between the Teaching model and vocabulary mastery towards students' Writing Achievement.

\section{Conclusions}

The teaching model has a significant effect on students writing achievement at State Vocational High School in Tangerang Regency. That is proved by Sig value $=0.000<0.05$ and $F_{\text {account }}=29.298$. There is a significant difference between students' writing achievement taught by the Duolingo game and the conventional teaching model. There is a significant effect of vocabulary mastery towards students writing achievement at State Vocational High School Tangerang Regency. That is proved by sig value $=0.000<$ 0.05 and $F_{\text {account }}=17.945$. It means a significant difference in students' writing achievement with high and low vocabulary mastery. There are no significant interactive effects of teaching model and vocabulary mastery towards students writing achievement at State Vocational High School Tangerang Regency. That is proved by sig value $=0.041<0.05$ and $\mathrm{F}_{\text {account }}=4.486$.

\section{References}

Ahmed, H. B. E. (2016). Duolingo as a Bilingual Learning App: a Case Study. Arab World English Journal, 7(2), 255-267.

Alexander, L.G, (1975). Practice and progress. London: Longman Group.

Aqib, Z. (2006). Penelitian tindakan kelas, Bandung: Yram Widya.

Beck, I.L., McKeown, M.G., \&Kucan, L. (2002). Bringing words to life: Robust vocabulary instruction.New York: Guilford Press.

Blanchard, Karen \& Christine R. (2003). Ready to write. New York: Person Education Inc.

Brain, G., and Claire, M. (1996). Writing from sources: A guide for ESL learners. California: Mayfield.

Brown, C, \& Susan, H, (1993). Writing matters writing skills and strategies for students of English. USA: Cambridge University Press.

Brown, D. (2001). Teaching by principles an interactive approach to language pedagogy. New York: Addison Wesley Longman.

Brown, D. (2004). Language assessment, New York: Longman.

Celce, M, \& Murcia, E. (2000). Discourse and context in language teaching. New York: Cambridge University Press

Departemen Agama RI.Al-qur'an dan terjemahanya. PT. SYGMA EXAMEDIA ARKANLEEMA

Dewi, U, (2010). How to write.Medan: La-Tansa Press.

Elbow, P. (1998). Writing with Power: Technique for mastering the writing process. (Second edition). New York: Oxford UniversityPress.

Gairns, R., \& Redman, S. (1991). Working with work as a guide to teaching and learning vocabulary. Cambridge: Cambridge University Press.

Harmer, J. (2004). How to teach writing. Edinburgh: Pearson Education Limited.

International Journal of English Linguistics (2013). Vol. 3, No. 1; 2013 ISSN 1923-869X E-ISSN 19238703 (Canadian Center of Science and Education) 
INFERENCE: Journal of English Language Teaching

Vol. 4, No. 3, December 2021 - March 2022

p-ISSN: $2615-8671$

e-ISSN: $2615-868 \mathrm{X}$

JaskovaBc, V. (2014). Duolingo as a new language-learning website and its contribution to e-learning education.Diploma Thesis (Brno: Masaryk University)

John, R. (2000). Assessing vocabulary. Cambridge: Cambridge University Press.

Langan, J. (2008). Sentence skills: A workbook for writers. (Eight editions). New York: The McGraw-Hill Companies, Inc.

Meyers, A. (2005). Gateways to academic writing: effective sentences, paragraphs, and essay, New York: Longman.

Sudijono, A. (2008). Pengantar statistik pendidikan. Jakarta: RajaGrafindo Persada.

Sudjana, (2002). Metode statistika.Bandung: PT. Tarsito

Suharsimi, A. (1993). Prosedur penelitian. Jakarta: Rineka Cipta.

Vesselinov, R., \& Grego, J. (2012). Duolingo effectiveness study.City University of New York, USA.

White, R and Arndt, V. (1992). Process writing. New York: Longman.

Yusro, M. (2013). Improving The VII F Students' Achievement in writing Descriptive Text by Using Spidergrams at SMP Negeri 2 Purwoharjo in the 2012/2013 Academic Year. Unpublished S1 